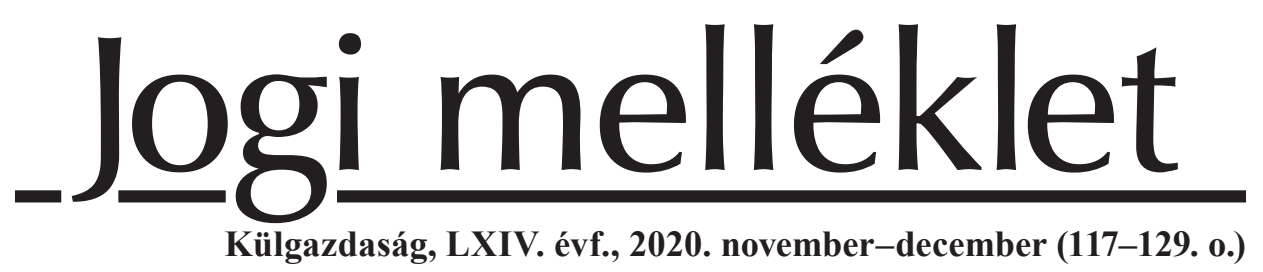

\title{
Viselkedéstudományi tapasztalatok a közegészségügyi szakpolitikai tervezésben az új típusú koronavírus-járvány idején \\ (Nemzetközi kitekintés) BELÉNYESI PÁL
}

A viselkedéstudományi tapasztalatok felhasználása a szakpolitika-alkotásban nem új keletü. Ez a módszertan azonban eddig Magyarországon még nem nyerte el az öt megillö pozíciót, annak ellenére, hogy a jogrendszer és a jogkövetö jogalanyok kapcsolatának a kulcsa elsösorban nem a pontosan meghatározott magatartást elöiró szabályok meghozatalában, hanem a megfelelöen elökészített, azaz elözetesen kipróbált és a jogalanyi alkalmazkodást megkönnyitö viselkedési-döntéshozatali környezet kialakitásában keresendö. A nemzetközi példák ezt támasztják alá a koronavírus okozta járványt illetöen is.

A cikk röviden körvonalazza a fenti gondolatmenet hátterét - követve a szerzönek a Külgazdaság hasábjain korábban megjelent tanulmányát (Belényesi, 2019) -, valamint bemutat néhány nemzetközi példát (Egészségügyi Világszervezet, ENSZ, közel-keleti tapasztalatok). A megismert példákból tanulható tapasztalatokat Magyarországon is alkalmazhatónak tartjuk. A helyes és hasznos magatartás választásának elösegitése pedig a jogalanyok szabálykövetési hajlandóságát javítja, a (jog)szabálykikényszeritési költségeket és a negativ externáliákat csökkenti, és így végsö soron a társadalom minden tagja jobban jár.

A kézirat első változata 2020. szeptember 5-én érkezett szerkesztőségünkbe. https://doi.org/10.47630/KULG.2020.64.11-12.117

Belényesi Pál igazgató, Brussels Consulting; egyetemi előadó a Károli Gáspár Református Egyetemen. E-mail: bp@brusselsconsulting.hu. 
Journal of Economic Literature (JEL) kódok: J18, Z18, D9, P35.

Kulcsszavak: viselkedés-gazdaságtan, tényalapú jogszabályalkotás, viselkedéstudomány, covid19.

\section{Abstract}

\section{Introduction to international examples of how behavioural economics helped during the first wave of the Covid-19 pandemic \\ PÁL BELÉNYESI}

The key to successful and effective public policies is evidence-based policy planning and rigorous policy monitoring. This is no first-page news but such approach is yet to gain impetus in Hungary. This study provides some practical-explanatory background to such policy making - following one of the author's earlier publication on the subject (Belényesi, 2019) -, focusing on and gathering internationally tested solutions from the time of the so-called first wave of the Covid-19 pandemic. The international examples have been collected on a selective basis focusing on practices of institutions with significant international influence. The aim was not to give a thorough overview of methods and ideas but to offer the readers different designs in diverse cultural environments, which have been tested, and, because of the applied nudges, provided the particular socio-cultural environment with positive results.

One of the conclusions of the study is that behavioural economics based and experimental, learning-driven policy-making could help legislators better understand individual behaviour, attitude and willingness to cooperate, therefore directly upping the effectiveness and success of public health policies. This, ultimately, could improve individual behaviour during crisis times, through little nudges, which, at the end of the day, would result in increased overall welfare to society. Another conclusion is that such examples could be of great use to Hungarian policy-makers, too, should the basis for such cooperation between experts and policy makers develop.

Journal of Economic Literature (JEL) codes: J18, Z18, D9, P35.

Keywords: behavioural economics, evidence-based policy-making, behavioural science, covid19.

\section{Bevezetés}

A szakpolitikai tervezés során figyelembe vett, jogalanyokra vonatkozó viselkedéstudományi jellemzők megértésének hasznossága nehezen vitatható. Ennek egyik oka, hogy az embereknek - azaz a szakpolitika által célzott jogalanyoknak - egyéni szinten manifeszt önkontrollproblémáik vannak, és ezért nem mindig a számukra a maximális egyéni jólétnövekedést eredményező döntést hozzák meg." E cikk a közegészségügyi szakpolitika terén hozott intézkedések fényében vizsgál- 
ja ezt az állítást úgy, hogy közelmúltbeli gyakorlatokat ismertet olyan országokból, ahol az új típusú koronavírus-járvány miatti korlátozó intézkedéseket az elsők között vezették be.

A közegészségügy területén különösen fontos a viselkedési és kognitív torzítások, heurisztikák és illúziók figyelembevétele, mert a járványügyi veszélyhelyzettel kapcsolatban az egyéni viselkedést, szándékot és akaratot gyakran a koronavírus terjedését és jellemzőit illető korántsem hiedelemmentes tudás határozza meg. A neoklasszikus közgazdasági iskola önérdekkövetö homo economicusát segíteni kell döntései meghozatalában a közegészségügyi intézkedések betartása terén is. Akkor is, ha sejtjük-tudjuk, hogy nem mindenki cselekszik kizárólagosan önérdekböl, kiváltképpen vészhelyzetben.

Ez a tanulmány elemez néhány olyan nemzetközi gyakorlatot, amelyet a kísérleti célú viselkedéstudományi eredményekre (viselkedéstudományi jelenségekre) építő tényalapú szakpolitikai (fact-based policy making) tervezést alkalmazó intézmények vezettek be vagy próbáltak ki a SARS-CoV-2 járvány első szakaszában szerte a világban. Tekintettel az új típusú koronavírussal való kontaktus következtében kialakuló heveny légúti fertőzés (COVID-19) miatt továbbra is fennálló globális járvány- és vészhelyzetre, a cikk az egyes intézkedések eredményeit érinti csak, és értelemszerüen nem tud mindent bemutatni. A folyamatban lévő, részeredményekkel bíró kísérleteket ezért nem említjük.

Az áttekintendő gyakorlatokra jellemző, hogy azok és a kapcsolódó kísérletek alapfeltételezése az volt, hogy a megszokott és „normális” élet - azaz a mindennapi rutin és beidegződések - hirtelen és tartósan megváltozott, valamint új viselkedési gyakorlatok alakultak ki a korlátozások következtében. Ennek a feltételezésnek a kiindulópontja, hogy napi tevékenységünk nagy része automatizált, úgynevezett rutincselekmény. Vitathatatlan, hogy a maszkviselés és a fizikai távolságtartás követelménye (physical distancing), ${ }^{1}$ a korlátozott időrendben és feltételek betartása mellett engedélyezett alapvető bevásárlási lehetőségek bevezetése, valamint több helyen a teljes lakhelyelhagyási tilalom elrendelése példátlan intézkedések voltak mindenki számára.

\footnotetext{
1 A köznyelvben elterjedt „,social distancing” fogalom használata nem egyszerüen rossz csak zsargon vagy aktuális bonmot, hanem a tárgyalt korlátozó intézkedés teljes félreértése. A fizikai távolságtartás (physical distancing) nem jelenti azt, hogy a társadalmi kapcsolatoknak is meg kellene szünniük (social distancing), sőt. A social distancing kifejezés félelmet kelt, elidegenedéshez vezet, és alapvető emberi mivoltukban korlátozza a társadalom egyes tagjait. Ennek hosszú távon komoly és kifejezetten káros egészségügyi hatásai lehetnek. (P1.: Banks, 2020)
} 
Az intézkedések mögött elsősorban közegészségügyi megfontolások álltak, de pontosan azonosítható gazdasági érdekek is megjelentek. A járványnak a gazdaságra kifejtett hatását viselkedés-gazdaságtani szempontból - bár rendkívül fontos és érdekes kutatási terület, és a közvetlen múltban több kutatás tárgya is volt (Duran et al., 2020) - ebben a cikkben nem érintjük.

Nehezen kérdőjelezhető meg, hogy társadalmi szinten is érzékelhető személyes mentális kihívások kísérték az első hullám alatt bevezetett korlátozásokat. A társadalmi szinten érezhető költségekben is megjelenő össztársadalmi jólétre kifejtett hatásokat ma még nem lehet pontosan meghatározni. Kevesen vitatják, hogy a másod- és harmadlagos hatásokat is csak hónapok, de inkább évek múlva lehet csak érezni (például a korlátozott egészségügyi ellátás következtében elmaradt betegségszürés miatt kialakult súlyosabb betegségek egészségügyi ellátást terhelő költségei, a munkahelyek bezárása miatt kialakult munkanélküliség társadalmi többletköltségei, a hosszú bezártságot követő mentális kihívások miatt kialakult személyi és csoportproblémák, a digitális oktatás és [home schooling] okozta képességbeli és taxatív tudás hiányát manifesztáló diákok tanulási nehézségei, stb.). A tanulmány szempontjából - és ezért célszerüen leegyszerüsítve - „összesített társadalmi jólléten”, „társadalmi jóléten”, illetve „társadalmi összjólléten” értjük az előbbi mondatban megjelölt negatív hatások és jelenségek minimalizálását, a minél kevesebb megbetegedéssel és halálesettel járó járványt, a lehető leghatékonyabb járványügyi intézkedések hatásának hosszú távú fenntartását, de a járvány megindulása előtti állapothoz képest egészségesebb életmódot folytató egyéneket is.

Ez a tanulmány azt mutatja be, hogy a viselkedéstudományi kísérletek eredményeit használó közegészségügyi szakpolitika hogyan tudta/tudja/tudná már a járvány ideje alatt is korrigálni a fenti, esetlegesen jelentkező nehézségeket úgy, hogy az egyéni viselkedések és attitüdök szintjén érinti, és a kötelezően követendő és elöírásszerű keretrendszert tartalmazó szabályrendszer nélkül, egy megfogalmazott közegészségügyi cél felé ,tereli” a jogalanyokat. Mindezt úgy, hogy a magatartásuk szabad megválasztásával ösztönzi őket egy jogkövető és egyben az össztársadalmi jól(l)étet is növelő irányba. Ezen megfontolást követi a Covid-19-et semlegesítő oltás elfogadásával kapcsolatos viselkedésiattitüd-kérdés is (Hallsworth \& Buttenheim, 2020). Itt jegyezzük meg, hogy az össztársadalmi jólét fogalma viszonylagosan értelmezendö, mert a széles körü korlátozások következtében minden országban és régióban gazdasági visszaesés következett be. Itt inkább ennek a korrigálására és a jólét egyéni, szociális jellegére utalunk. A módszertan széles körű alkalmazható- 
sága miatt a szövegben a szakpolitikai és közegészségügyi utalások egymással felcserélhetők. A terminus technicusok egymást váltó szövegbeli alkalmazása inkább a könnyebb olvasást segíti.

A cikk interdiszciplináris jellege miatt érdemes röviden tisztázni a gondolatmenet logikáját, amely alapvetően a célszerüség elvét követi. Az általános alkalmazást bemutató ENSZ-anyagot és az azt kísérő gyakorlatot követően kitérünk két olyan jelenségre, amelyek alapvetően befolyásolták a jogalanyok viselkedését a korlátozások alatt. Ezek: a lezárások időzítése és az alkalmazkodási akarat kapcsolata, valamint a korlátozások feloldása utáni magatartást jellemző ún. fresh start hatás. Ezt követően bemutatjuk, hogy milyen javaslatokkal állt elő az egyesült királyságbeli Behavioural Insights Team (BIT) annak érdekében, hogy az attitüdökben pozitív változásokat lehessen elérni. A tanulmányt szintézis és konkrét javaslatok zárják.

\section{Esettanulmányok és kísérletek}

Olyan példákat mutatunk be, amelyek megértése az azokat alkalmazó szervezetek általános ismerete miatt mindenki számára egyszerübb. A közel-keleti példa tekintettel van arra, hogy a kulturális környezet alapvetően befolyásolhatja az egyének magatartását és attitüdjét, ugyanakkor a járvány második hulláma idején egy fokozottan érzékenyebb csoportra, a fiatalokra vonatkozóan tartalmaz megfontolandó gondolatokat.

A racionális döntéshozataltól eltérő magatartást befolyásoló torzítás diszciplínán belüli helyére az egyes gyakorlatok bemutatásakor nem térünk ki - arra nem lenne elegendő hely ezen írás keretei között -, de általánosságban megjegyezzük, hogy azokat a gazdasági viselkedéstan (viselkedés-gazdaságtan, behavioural economics) által az utóbbi negyven évben megalapozott fogalmakat használjuk, amelyek alapvetően a torzítások/illúziók/heurisztikák hármas tagolásába illenek (Smith, 1759; Herbert, 1983; Kahneman-Tversky, 1974, 1979; Thaler, 1980; Kahneman, 2003; Molnár, 2006; Jáki, 2012).

Az Egészségügyi Világszervezet „,viselkedési” segédanyaga

Az Egészségügyi Világszervezet már 2020 áprilisában közzétette a világjárvánnyal kapcsolatos viselkedési magatartások kezelésére vonatkozó útmutatóját. Az útmutató alapjai, amelyek a helyi és országos szintủ egészségügyi szervezetek és 
közegészségügyi intézetek munkáját hivatottak segíteni, az Erfurti Egyetem által végzett rendszeres attitüdvizsgálatok és felmérések voltak.

Ezek a heti gyakorisággal végzett adatgyüjtések a megkérdezettek félelemérzetét, a korlátozó intézkedések betartásának nehézségeit, valamint az intézkedésekbe vetett bizalmat mérték és elemezték. Az adatgyüjtésnek és adatelemzésnek a célja a konspirációs mítoszok kialakulásának gyors és hatékony megelőzése és letörése volt úgy, hogy ahhoz - és a közegészségügyi szakpolitikai célok eléréséhez - a jogalanyok alkalmazkodását és alkalmazkodni akarását használják fel elsősorban. Az elemzéseknek köszönhetően a német hatóságok számára például világossá vált, hogy a fiatalok sokkal komolyabb pszichológiai megpróbáltatásoknak vannak kitéve, így ezt a társadalmi csoportot más irányított intézkedésekkel kell kezelni.

El kell azonban ismerni, hogy a kérdéses ENSZ-útmutató egyedi jelentősége nem kimagasló, mert nem ad konkrét útmutatást az egyes viselkedési attitüdökre és az azokkal kapcsolatos egyedi kérdésekre. Ugyanakkor hangsúlyozni kell azt is, hogy az ENSZ szintjén kifejezetten és gyorsan kezdődött el az ilyen irányú gondolkodás. A világjárvány kezelésének szempontjából ennek kiemelt jelentősége lehet már a közvetlen jövőben is.

Az ENSZ Fejlesztési Programjának néhány kezdeményezése

Az ENSZ Fejlesztési Programja már egy ideje használja a fejlődő országokban a viselkedés-gazdaságtan és a kapcsolódó pszichológiai felfedezések újításait, különösen az egyes programtervezési szakaszokban. A Covid-19 terjedésének megakadályozásakor és a bevezetett korlátozó intézkedések alkalmazásakor az ilyen típusú viselkedési alapú design thinking kiemelt jelentőségűvé vált.

A Fejlesztési Program ún. Youth Leadership Alprogramja 2020 tavaszán szervezett egy workshopot, amelynek célja azon kognitív és viselkedési torzítások megértése volt, amelyek az új típusú koronavírus-járvány miatti korlátozásokkal kapcsolatosan a leginkább befolyásolták a korlátozások elfogadását és betartását kísérő emberi magatartásokat. Nem meglepően a leggyakrabban előforduló torzítás az úgynevezett túlzott optimizmus vagy optimista jövőkép, az indokolatlan magabiztosság, a status quo torzítás, a jelenhez való ragaszkodás (hiperbolikus leértékelés), az indokolatlan félelem, valamint az úgynevezett isteni akaratba való belenyugvás lett. Az ötletgyár különlegességeként említhető meg, hogy az azonosított torzítások szakpolitika-tervezésre való alkalmazhatóságát egy speciális korosztálycsoport, a 
Viselkedéstudományi tapasztalatok a közegészségügyi szakpolitikai...

fiatalok javaslatai alapján vették figyelembe. Az említett torzítások kezelésére a következő javaslatok születtek.

Szomáliában és Libanonban a közösségi vezetők higiéniát hangsúlyozó - kézmosás, távolságtartás - és népszerüsítő szerepét tesztelték: olyan ismert közösségi szereplőket kértek fel videók és tájékoztató szövegek elkészítésére, akiknek egy adott csoportban kiemelt szerepük volt. A cél az általános közegészségügyi szempontok megismertetése volt helyi szinten, valamint a célzott és elvárt közösségi viselkedés „brandesítése”. Ennek oka, hogy az emberek jellemzően alulértékelik a „helyes viselkedést", például a kézmosás és fizikai távolságtartás fontosságát, ezzel szemben túlértékelik az egészségtelen magatartást. A tevékenységek egyértelmúen az utánfutóhatás (vagy „tarts a győztessel” hatás) és a társadalmi jóváhagyás jelenségeit tartották szem elött (bandwagon effect, social context/social confirmation), azaz arra épültek, hogy az emberek viselkedésének meghatározó eleme, hogy arról egy adott közösség miképpen vélekedik. Ehhez hasonlóan az élményhatás torzítását (affect heuristic élményheurisztika) is igyekeztek a bevezetendő szakpolitikában alkalmazni, kiemelve a mások - bajba jutottak - segítésének és a figyelemfelhívás fontosságát. Az intézkedésekkel kapcsolatos tapasztalatok mindkét országban pozitívak voltak.

A lezárások időzitése és az alkalmazkodási szándék

A korlátozó intézkedések bevezetésekor az egyik legfontosabb kérdés azok hoszsza és szigorúsága volt, nemcsak a jogalanyok, hanem a gazdasági szereplők számára is. Az intézkedések betartatása, azok kommunikációja az emberi egészség és társadalmi jólét szempontjából központi fontossággal bír. Ha a lezárásokat nem tartják be - vagy nem betarthatók -, akkor nem az egészség védelmét szolgálják, hanem egyszerüen csak gazdasági veszteséget okoznak.

Bizonyára többen emlékszünk arra, hogy nem tudtuk, meddig tartanak az intézkedések, mikor és kikre vonatkozóan szigorodnak és mikor enyhülnek a korlátozások. Ez a krízishelyzetben megélt úgynevezett radikális bizonytalanságérzetet (radical uncertainty) fokozta. A legfrissebb eredmények is igazolják azonban a korábban már ismert feltételezéseket: a hosszabb időre tervezett és szigorúbb korlátozások azonnali bevezetése, majd a fokozatos enyhítés hatékonyabb jogalanyi alkalmazkodáshoz vezet (Thaler, 2016), mint a rövidebb és folyamatosan megújuló és szigorodó intézkedések (például a jelenlegi világjárvánnyal kapcsolatban az Egyesült Királyság, az Egyesült Államok és Brazília esetében) (Harman \& Delbridge, 2020). A jelenség alapja a viselkedés-gazdaságtanban jól ismert úgynevezett veszteségtől 
való félelem (loss aversion), amelynek lényege, hogy egy bizonyos mértékü veszteségtől jobban félünk, mint amennyire az ugyanakkora mértékü nyereségre vágyunk (Tversky \& Kahneman, 1979). Ez a jelenség a korlátozó intézkedésekkel kapcsolatban ugyanúgy jelenik meg, mint az egyéni döntéshozatalban.

A megszorító intézkedésekhez való alkalmazkodási akarat mértéke jellemezhető továbbá a hiperbolikus leértékelés jelenségével is. A fogalom lényege, hogy az egyéni döntéseket annak alapján tervezzük, hogy a rövid távon érzékelhető, de kisebb haszonnal járó jutalmakat kognitív hiányosságok miatt többre értékeljük, mint az időben később realizálódó nagyobb jutalmakat (Ainslie \& Haslam, 1992). Ez egyértelmúen azt jelenti, hogy a szigorú intézkedésekkel kezdődő és lassanként egy-egy kisebb szabadságot hamarabb és fokozatosan megengedő intézkedések bevezetése az emberekben nagyobb fokú boldogságérzetet és alkalmazkodást eredményez, mint egy egyszeri, nagy engedmény kilátásba helyezése.

Egy másik döntéshozatalt viselkedési alapon torzító megfigyelt jelenség a cél folytonos változtatásának az együttműködésre gyakorolt negatív hatása (goal gradient effect), ami hangsúlyozottan jelent meg a lezárások alatt is. Az olaszországi korlátozó intézkedésekhez kapcsolható jogkövető magatartás vizsgálata kimutatta (Briscese et al., 2020), hogy a reprezentatív mintában részt vevők között megfigyelhető volt, hogy egy hipotetikus intézkedéshosszabbítás alacsonyabb fokú megfelelöségi magatartást eredményezett, mert az egyének rövidebb ideig tartó lezárásokban bíztak. Következésképpen, legalábbis Olaszországban, az emberi alkalmazkodást jobban elősegítenék a hosszabb időre tervezett, majd közegészségügyi indokok alapján hatósági engedékenységgel fokozatosan kivezetett korlátozások, mint a bizonytalan és rövid idejü, „hamarosan engedmények lesznek” jellegű szakpolitika. Nehezen vonható kétségbe, hogy az átláthatóan megfogalmazott és folyamatosan kommunikált intézkedések úgyszintén nagyobb fokú alkalmazkodást eredményeznek, mert segítenek a veszélyhelyzettel kapcsolatban támaszt találni a bizonytalanságban. Különösen fontos ez a lezárásokkal kapcsolatban, mert egy bizonytalan kimenetelü veszélyhelyzetben az egyéni döntéshozatal még inkább befolyásolttá válik a félelemérzet fokozása miatt (a félelem miatt a veszélyt közelinek, azonnalinak érezzük). Ez gyakran követi a következő folyamatot: „,a veszély tényszerü érzékelése - emocionális reakció - elöítéletek kialakulása és manifeszt diszkriminatív magatartás a veszéllyel kapcsolatba hozhatókkal szemben - pánik” (J. J. Van Bavel et al., 2020). A compliance-t segíti még - a tapasztalatok alapján - egy adott a társadalmi csoport tagjainak a csoportnak mint egésznek való megfelelőségi akarata (social and 
Viselkedéstudományi tapasztalatok a közegészségügyi szakpolitikai...

cultural influence), a társadalmi visszajelzés - azaz az alkalmazkodó csoporttagok hatása is (Wood, 200; Cialdini, 2004; Berkowitz, 2005; Harman \& Delbridge, 2020).

$A$,fresh start" hatás

Az egyesült királyságbeli BIT természetesen több területen is segítette a döntéshozót ebben az időszakban is. A BIT egyik ilyen tevékenysége a viselkedéstudományban ismert úgynevezett „fresh start” jelenséget és az újonnan bevezetett rutinszerủ magatartásoknak a korlátozások feloldását követő időszakban való megtartását vizsgálta (Dai et al., 2014; Price et al., 2018).

Az újrakezdés-effektus jelen helyzetben értelmezhető lényege, hogy a korlátozások következtében sokan vezettek be pozitív életmódváltozásokat a mindennapjaikba, a járványügyi intézkedések, azaz külső kényszer hatására. Például az elérhető és érzékelhető tiszta levegő fontosnak tartása, a barátok gyakoribb felkeresése telefonon, a közeli társadalmi csoportokban és közösségekben való aktívabb részvétel, a gépjármüvek használatának mellőzése és az így kialakuló alacsonyabb légszenynyezettség, a gyakoribb testedzések és tréningek bevezetése, valamint a gyerekekkel való idő eltöltésének minőségi és mennyiségi javulása mind ilyen változásnak tekinthetök.

Az ezekkel kapcsolatos, aggregát egyéni határhasznot meghaladó speciális társadalmi jólétnövekedés könnyen érthető. A BIT vélekedése szerint azonban az újonnan kialakult környezetet kímélő és másokra nagyobb tekintettel lévő rutincselekmények - ha ismét megváltozik körülöttünk az életviteli feltételrendszer - automatikusan nem maradnak a mindennapjaink részei. Éppen ezért a BIT egy csoportja kidolgozott egy viselkedéstudományi eredményekre épüló javaslatcsomagot annak érdekében, hogy a magatartás-változások akár a korlátozások feloldása után is fenntarthatók legyenek. ${ }^{2}$

A BIT javaslata az úgynevezett viselkedési ösztönzők (nudge) alkalmazása köré csoportosítható (Thaler \& Sunstein, 2008; Szántó \& Dudás, 2016). Az egyik ilyen tervezet a tisztább környezet, a kisebb mértékủ gépkocsihasználat és az ezzel párhuzamosan kialakuló testmozgás megtartása mellett érvelt. Lényege, hogy a gépjármühasználat mellőzésével kialakult biciklihasználat, sétálás megtartható lenne például úgy, hogy az úgynevezett „utolsó kilométert” (last mile walking) nem gépjárművel, hanem a fenti lehetőségeket kihasználva, testmozgásként tennék meg

\footnotetext{
${ }^{2}$ https://www.bi.team/blogs/life-after-lockdown-an-opportunity-for-change/
} 
az emberek. Ennek érdekében a helyi önkormányzatoknak a müködő és széles körben használt digitális alkalmazásokkal kellene összefogniuk (CityMapper, Google Maps stb.), például úgy, hogy csendesebb és tisztább utakat jelölnek ki a felhasználók számára erre az utolsó szakaszra. Az iskolába vezető gyalogút megjelölése lábnyomokkal, a területen belüli sebességkorlátozás csökkentése, valamint a gyalogos közlekedés munkahelyi díjazása (reward-based exercise) szintén olyan változtatások, amelyek a tapasztalatok szerint sikerrel ösztönzik az egyéneket a magatartásuk minimális változtatására.

A mindennapi bevásárlással kapcsolatban is megváltoztak szokásaink. A korlátozások ideje alatt többet föztünk otthon, amihez több alapanyagot vásároltunk. A társadalom egy része, a BIT felmérései alapján, az Egyesült Királyságban például az alapanyagokat jobban megválogatta - elsősorban az internetes rendeléseknek köszönhetően -, valamint ételt is kevesebbet pazarolt. Ennek következtében mind egészségesebb, mind környezetbarátabb módon étkezett. Az étkezési szokásokkal kapcsolatban azonban vannak olyan felmérések is, amelyek azt mutatják be, hogy Spanyolországban az emberek jelentős része vagy pont ugyanúgy, vagy egészségtelenebbül étkezett a lezárások alatt, mint azelőtt. Például kevesebb halat ettek és több édességet fogyasztottak (Romeo-Arroyo et al., 2020). A BIT szerint ezeket a kialakult magatartásokat és rutincselekményeket, amennyire lehet, meg kellene tartanunk. Ezt elősegítendő a bevásárlóközpontokban olyan ösztönzéssel segített választási architektúrát kellene alkalmazni, amely az interneten keresztül megjelenő, egészségesebb és fenntarthatóbb táplálkozást tükröző választási preferenciákat ülteti át a korlátozások feloldása utáni offline mindennapokba.

\section{Összefoglalás}

A stabil módszertanra épülő tény- és bizonyítékalapú szakpolitikai tervezés ma már minden demokratikus és költséghatékonyságot szem előtt tartó szakmai irányítás egyik legfontosabb célkitúzése és alapja. A közegészségügy, a járványhelyzet kezelése, a védekezési intézkedések mandatórikusságával (pontosan meghatározott és követendő magatartások előírása által) elérni kívánt eredmények csak részben lehetnek sikeresek, ha az egyének nem követik az intézkedéseket. A közegészségügyi intézkedések nem kívánt negatív hatása az emberek viselkedésében fellelhető attitüdváltozások miatt komolyan befolyásolhatja az intézkedések sikerét (Baddeley, 2020). A jogkövető magatartás elsősorban a viselkedési és alkalmazkodási 
szándékon áll vagy bukik. A megszokott életvitelt alapvetően és tartósan befolyásoló szigorú intézkedéseket csak akkor lehet betartani - gazdasági értelemben az egyéni szinten realizálódó hasznot időlegesen a társadalmi összjólét érdekében félretenni -, ha nemcsak az ideiglenes attitüdök, hanem a bevett magatartások is átalakulnak, tartósan is, amennyiben ez indokolt. Az egyéni, csoportos vagy éppen egy pontosan meghatározható régióra jellemző magatartás-vizsgálat a bevezetendő intézkedések fényében olyan információval tud szolgálni, amelyet jelen ismereteink szerint más eljárás nem tud pótolni.

Az új típusú koronavírus-járvány első hullámának idején hozott intézkedések egyelőre közel sem szeplötlen sikere a közeljövőben valószínüleg újra kényszerhelyzetbe hoz sok országot. A „második hullám” közegészségügyi megközelítése már tükrözi: drasztikus magatartás-változtatási megoldásokkal sem lehet(ett) megakadályozni, hogy a vírus újra felüsse a fejét, ráadásul a korábbinál jóval nagyobb lakossági penetrációban. Ezért kiemelten fontos, hogy a vírus terjedését fékezni hivatott intézkedéseket megfelelő környezetben, viselkedési és kognitív torzításokat szem elött tartva, a jogalanyok tényleges reakcióját figyelembe vevő helyzetben teszteljük, majd az így szerzett információkat azonnal visszacsatolhatjuk a szakhatóságok felé. Amint az első hullám alatt is láttuk, az intézkedések hatékonysága, a szakpolitika - jelen esetben a közegészségügyi intézkedések - eredményessége ezektől nagymértékben függ. A WHO ennek a felismerésének hangot adott, amikor 2020. szeptember 3-án összehívta a Viselkedéstudományi Ismeretek és az Egészséget Szolgáló Tudomány Tanácsadó Csoportjának (Technical Advisory Group on Behavioural Insights and Sciences for Health) első ülését.

A Magyarországon alkalmazható viselkedéstudományi tapasztalatok alapján megalkotott intézkedések bevezetésének feltétele, hogy a jogalkotónak erre igénye legyen. Ennek a gondolatnak része kellene, hogy legyen a fizikai távolságtartás, a maszkviselésre vonatkozó elöírások követése, valamint a jövőbeni oltás elfogadása és az oltást követő elvárt viselkedés betartása. Ha ez az igény, akár helyi szinten, azonosítható, akkor a megfelelő szakmai felkészültséggel rendelkező mühelyek feladata a tesztpéldák kidolgozása, és a jogalkotó támogatásával azok kipróbálása. A jogalkotó szervek és felkészült szakmai mühelyek folyamatos együttmüködése hiányában a külföldi gyakorlatok hazai környezetben való, helyi kulturális és társadalmi berendezkedésre reflektáló bevezetése illúzió marad. Az elmaradt viselkedési ösztönzők hatása pedig a tervezett közegészségügyi-szakpolitikai célok hiányos eléréséhez vezethet. 


\section{Hivatkozások}

Ainslie, G. \& Haslam, N. (1992). Hyperbolic discounting. In Loewenstein, G. \& Elster, J. (Eds.), Choice over time. Russell Sage Foundation, New York, 57-92.

Baddeley, M. (2020). Hoarding in the age of COVID-19. Journal of Behavioral Economics for Policy, 4(S): 69-75.

Banks, A., Social vs. Physical Distancing: Why It Matters. The importance of social connection in the pandemic. Psychology Today, 12 Apr., 2020.

van Bavel, J. J. et al. (2020). Using social and behavioural science to support COVID-19 pandemic response. Nature human behaviour, 4(5), 460-471.

Belényesi, P. (2019). Viselkedéstudományi eredmények beépítése a szakpolitikai folyamatokba. Külgazdaság, 63(5-6), 47-63.

Berkowitz, A. D. (2005). An overview of the social norms approach. In Stewart, L. \& Lederman, L. C. (Eds.) Changing the Culture of College Drinking: A Socially Situated Health Communication Campaign. Hampton Press, Creskill, NJ.

Briscese, G., Lacetera, N., Macis, M. \& Tonin, M. (2020). Compliance with Covid-19 Social Distancing Measures in Italy: The Role of Expectations and Duration. NBER WP Series, Working Paper 26916. https://www.nber.org/papers/w26916.pdf

Cialdini R.B. \& Goldstein, N.J. (2004). Social influence: compliance and conformity. Annual Review of Psychology, 55, 591-621. https://doi.org/10.1146/annurev.psych.55.090902.142015

Dai, H. et al. (2014). The Fresh Start Effect: Temporal Landmarks Motivate Aspirational Behavior. Management Science, 60(10), https://doi.org/10.1037/e513702014-058

Duran, S. et al (2020). Understanding Coronavirus Pandemic in the Context of Behavioural Economics. El Ruha $7^{\text {th }}$ International Conference on Social Sciences. August 3-5, Tripoli, Libya.

Hallsworth, M. \& Buttenheim, A. (2020). Challanges Facing a Covid-19 Vaccine: A Behavioral Science Perspective. Behavioural Scientist, August 11, https://behavioralscientist.org/challenges-facing-acovid-19-vaccine-a-behavioral-science-perspective/

Harman, O. \& Delbridge. V., Behavioural economics of lockdown compliance: in search of lost time and well-behaved neighbours. 4 May, International Growth Centre. https://www.theigc.org/ blog/behavioural-economics-of-lockdown-compliance-in-search-of-lost-time-and-well-behavedneighbours/

Herbert, S. (1983). Reason in Human Affairs. Stanford University Press, Stanford.

Jáki, E. (2012). Az optimista EPS elörejelzési hiba viselkedéstani okai-Az EPS elörejelzések vizsgálata magyar és osztrák viszonylatban. PhD-disszertáció, Budapesti Corvinus Egyetem https://doi. org/10.14267/phd.2013002

Kahneman, D. \& Tversky, A. (1974). Judgment Under Uncertainty: Heuristics and Biases. Science, 185 (4157), 1124-1131. https://doi.org/10.1017/cbo9780511809477.002

Kahneman, D. \& Tversky, A. (1979). Prospect Theory: An Analysis of Decision under Risk. Econometrica, 47(2), 263-291. https://doi.org/10.21236/ada045771

Kahneman, D. (2003). A perspective on judgement and choice: Mapping bounded rationality. American Psychologist, 58(9), 697-720. https://doi.org/10.1037/0003-066x.58.9.697

Molnár, M. A. (2006). A magyar tőkepiac vizsgálata pénzügyi viselkedéstani módszerekkel. PhDdisszertáció, BCE, Gazdálkodástudományi kar, Befektetések és Vállalati Pénzügy tanszék.

Price, L. L., Coulter, L. A., Strizhakova, J. \& Schultz A. E. (2018). The Fresh Start Mindset: Transforming Consumers' Lives, Journal of Consumer Research, 45(1), https://doi.org/10.1093/jcr/ucx115

Romeo-Arroyo, E., Mora, M. \& Vázquez-Araújoa, L. (2020). Consumer behaviour in confinement times: Food choice and cooking attitudes in Spain. International Journal of Gastronomy and Food Science, 21, 100226. Published online: 2020 Jun 4. https://doi.org/10.1016/j.ijgfs.2020.100226 
Smith, A. (1759). The Theory of Moral Sentiments. Printed for Andrew Millar, in the Strand; and Alexander Kincaid and J. Bell, in Edinburgh.

Szántó, R. \& Dudás, L. (2017). A döntési helyzetek tudatos tervezésének háttere. A nudge fogalma, módszerei és kritikái. Vezetéstudomány/Budapest Management Review, 68(10), 48-57. https://doi. org/10.14267/veztud.2017.10.06

Thaler, R. (1980). Toward a positive theory of consumer choice. Journal of Economic Behavior \& Organization, 1(1), 39-60. https://doi.org/10.1017/cbo9780511803475.016

Thaler, R. \& Sunstein, C. (2008). Nudge. Penguin Books, London.

Thaler, R. (2016). Misbehaving: The Making of Behavioral Economics. W.W. Norton \& Company, New York.

Wood, W. (2000). Attitude change: persuasion and social influence. Annu. Rev. Psychol., 51, 539-570. https://doi.org/10.1146/annurev.psych.51.1.539 